\title{
Mobile Communication and Civil Society: Linking Patterns and Places of Use to Engagement with Others in Public
}

\author{
Scott W. Campbell \& Nojin Kwak \\ Department of Communication Studies, University of Michigan, Ann Arbor, MI 48104, USA
}

This study examined whether and how mobile communication influences the extent to which one engages with new people in public settings. Contrary to our expectation, general use of the technology in public did not detract from conversing with strangers. Shifting focus from where one uses the mobile phone to how it is used, we found that uses for coordination and news each lead to increased conversations with strangers in public settings, while relational use detracted from them. The findings also reveal an interactive effect such that those who use mobile technology for news and frequently use it in public were more likely to engage with strangers in public. The discussion offers interpretation of the findings and directions for future research.

doi:10.1111/j.1468-2958.2010.01399.x

The so-called public realm is a vital component of civil society because it minimizes the segregation of citizens along traditional lines of difference such as values, opinions, gender, race, ethnicity, and life stage (Hampton, Livio, \& Goulet, 2010). Indeed, exposure to diversity is regarded as a cornerstone of deliberative democracy (Bessette, 1980, 1994; Cohen, 1989; Habermas, 1989; Putnam, 2000), and public settings foster this through unintended encounters with others. As Sunstein (2001) argues, the possibility for these encounters is important because they may lead to the sharing of information, exposure to alternative viewpoints, and curiosity about new topics resulting in further investigation of them. In fact, Sunstein contends that unplanned exposure to information and views is a fundamental requirement for a well-functioning system of free expression.

In recent years, the emergence of mobile communication has altered the very nature of public forums by providing new opportunities for individuals to connect with absent others. The concern here is that these mediated connections may inhibit opportunities for conversation to spark up among strangers, with deleterious consequences for an open, active, and diverse civil society. Thus, the purpose of this study is to assess how mobile communication affects the frequency with which one engages in conversation with strangers in public settings.

Corresponding author: Scott W. Campbell; e-mail: swcamp@umich.edu 


\section{Hypothesized effects of mobile communication in public settings}

Mobile communication has rapidly emerged as a nearly ubiquitous resource for connecting friends and family members as well as coordinating daily life activities. In fact, it is the fastest diffusing communication technology on the planet-ever (Castells, 2009). Mobile telephony is ubiquitous with regard to not only how many people use it but also where they use it. The affordance of mobility allows for virtually anytime-anywhere connectivity, making this private social resource a matter of public concern. One concern is that its use in public challenges norms for behavior around others. Indeed, studies show that most individuals are irritated by others' use of the technology in public, particularly with regard to voice calls, giving rise to a host of new strategies to curb such use around copresent others (Katz, 2006; Ling, 2004; University of Michigan, 2006). In addition, mobile communication in public (any type of use) can disrupt new social encounters by serving as a barrier between the user and copresent bystanders. Ling (2008) explains:

While generally we must be open to both intimates and strangers when we interact in daily life, the mobile phone tips the balance in the favor of the intimate sphere of friends and family. In a situation where there otherwise might have been the opportunity for talking with a stranger (e.g., waiting for a bus or standing in a checkout line), we can instead gossip, flirt, or joke with friends, intimates, or family members. (pp. 159-160)

Gergen (2008) argues that intensive mobile-mediated contact among friends, family, and intimates hinders open public dialogue among autonomous individuals, thus replacing this basic element of civil society with small enclaves of strong network ties, which he characterizes as monadic clusters. There is some support in the research so far that frequent mobile communication in these close-knit networks can lead to social insularity (Habuchi, 2005; Ling, 2008), illustrated by less civic/political engagement (Campbell \& Kwak, in press) and less political discourse with nonintimates (Campbell et al., 2010). Additional empirical research is needed to examine whether its use specifically in public settings contributes to this type of trend by hindering conversations with copresent strangers.

Theoretically, Gergen's (2002) argument about absent presence is a useful framework for developing hypotheses about the effects of mobile phone use in public. Absent presence refers to being socially removed from one's physical surroundings and others in them through the use of communication technology. As Gergen contends, "[o]ne is physically present but is absorbed by a technologically mediated world of elsewhere" (p. 227), thus immersing them in "private as opposed to collective worlds" (p. 230). He is especially concerned about the mobile phone's ability to foster absent presence but acknowledges that this is not a new problem and can occur through all types of media. Indeed, there is a long tradition of carrying around books, magazines, and newspapers to read in public places. However, as opposed to these monologic (i.e., one-way) media, mobile communication is dialogic in that it fosters reciprocal flows of interaction. Gergen argues that dialogic media are more 
consuming because "one participates in the construction of the world, and this construction can be uniquely tailored to, and expressive of, one's individual circumstances ... In effect, the present is virtually eradicated by a dominating absence" (p. 231). Furthermore, for many, the mobile phone is primarily used for maintaining existing relationships (Campbell \& Kwak, in press; Ling, 2008), which as Gergen argues, favors greater depth in relationships at the expense of breadth when users are withdrawn from others in their physical surroundings. This brings us full circle to a point made earlier: "While generally we must be open to both intimates and strangers when we interact in daily life, the mobile phone tips the balance in the favor of the intimate sphere of friends and family" (Ling, 2008, p. 159).

Drawing from this line of research and theory, we hypothesize that $(\mathrm{H} 1)$ mobile phone use in public settings leads to having fewer conversations with strangers in these settings. For comparative insight, we examine the effects of mobile communication in public with those of various other portable media that are popular today, including laptops, digital music devices, and print media. Because dialogic media (in this case, mobile phones and laptops) are theorized to contribute to greater absent presence, we hypothesize $(\mathrm{H} 2)$ that they have a stronger impact on disengaging with strangers in public settings than the monologic media included in this study (music devices and print media).

\section{Hypothesized effects of differential forms of mobile communication}

In addition to how often individuals utilize mobile technology in public, this study also accounts for different ways in which they generally tend to use it. There is an abundance of empirical evidence establishing that differential forms of media use shape media effects. For example, informational uses of both traditional media (e.g., television) and new media (e.g., Internet) tend to have positive effects on civic life, while certain recreational uses have yielded different outcomes (Besley, 2006; Norris, 1996; Shah, Cho, Eveland, \& Kwak, 2005; Shah, Kwak, \& Holbert, 2001; Sotirovic \& McLeod, 2001). These trends for different patterns of media use can be understood through the lens of the uses and gratifications (U\&G) tradition (Blumler \& Katz, 1974). Although most applications of U\&G emphasize the ways in which motivations shape media use behavior, the U\&G framework also posits that usage patterns play an integral role in shaping social outcomes. In fact, Finn (1997) argues that the "most critical" components of $U \& G$ theory are "(a) the social and psychological origins of audience needs, (b) the different patterns of media exposure that purportedly result, and (c) the differential engagement in other activities" (pp. 508-509). This study draws from these elements of the U\&G framework, particularly the last two, which Finn identifies as "most critical" (i.e., patterns of media use and engagement in other activities). That is, in addition to how often one uses mobile technology in public, this study examines how differential forms of its use affect engagement with strangers in public settings.

To identify key mobile phone usage patterns, we draw from the seminal work of Ling and Yttri (1999, 2002; Ling, 2004), who classify two overarching forms of mobile-mediated interaction-instrumental and expressive. Instrumental use 
entails logistical coordination of day-to-day activities, whereas expressive use refers to maintaining personal relationships and self-presentation. They also acknowledge safety/security as a fundamental motivation for adopting mobile telephony, although for many, this tends to be a latent use (i.e., a sense of security) rather than a manifest daily pattern. As it has evolved into a hybrid medium supporting both interpersonal and mass communication, instrumental use of mobile technology has expanded to include getting and exchanging news (Campbell \& Kwak, in press; Campbell, et al., 2010; Wei, 2008). The rise of mobile telephony as a means of surveillance and information exchange is evidenced by mobile-mediated updates during the 2008 U.S. presidential election (Aleo-Carreira, 2008) and a spike in text messaging on its final day (AT\&T, 2008). Thus, we add informational use of mobile telephony to the other core usage patterns of coordination and maintaining relationships. These core usage patterns - logistical, relational, and informational - are reflected in other U\&G studies of mobile communication technology as well (Campbell \& Kwak, 2010; Leung \& Wei, 2000; Wei, 2008; Wei \& Lo, 2006).

Going beyond the general prediction that differential forms of mobile communication shape consequences of its use, we consider each of the select usage patterns to hypothesize how they influence engagement with strangers in public settings. With regard to coordination, there are reasons to anticipate that this form of mobile phone use may actually contribute to engaging with strangers in public settings. Mobile communication softens traditional restraints of time and space, affording new opportunities to coordinate daily life activities on the fly (Ling, 2004; Ling \& Campbell, 2009). This heightened flexibility means that the so-called microcoordinators (Ling, 2004; Ling \& Yttri, 1999, 2002) can make plans with others while going about their daily business. They are not tied to a particular location in their efforts to coordinate with others and therefore have greater opportunity to move about from place to place while scheduling and refining daily life activities. In this way, mobile communication allows for increased opportunity for busy people to be in public settings with others around. Another way mobile-mediated coordination can heighten one's presence in public settings is by using them as points of locality for meeting up with others (Humphreys, 2007; Ling, 2004; Ling \& Yttri, 1999, 2002). Even if they typically arrange for these meet-ups with people they already know, this use of public space opens up new opportunities to engage with people they do not know when strangers occupy shared space. For these reasons, we anticipate that (H3) the more one utilizes mobile communication for purposes of coordination, the more likely one will be to engage in conversations with others in public settings.

There are reasons to anticipate that heavy use of mobile technology for maintaining personal relationships may have a very different effect on engagement with strangers. As noted earlier, some scholars have found that intensive mobile communication among personal network ties can, in some circumstances, lead to social insularity (Habuchi, 2005; Ling, 2008). The concern here is that staying continually connected to one's private sphere of relationships can focus one's attention socially inward. In this case, the same flexibility that frees up movement during coordination 
allows one to weave personal network interactions throughout everyday life, essentially allowing one to stay in perpetual contact (Katz \& Aakhus, 2002) with close friends, family members, and intimates. Gergen $(2002,2008)$ argues that this aspect of mobile communication contributes to a form of social withdrawal, characterized by the primacy of maintaining existing close relationships over developing new ones. Drawing from this line of reasoning, we hypothesize $(\mathrm{H} 4)$ that frequent relational use of mobile telephony will be associated with fewer interactions with strangers over time.

As for informational use, there is a long tradition of scholarship suggesting that getting and discussing news have positive effects on public life by boosting civic engagement, political knowledge, and a collectivistic orientation (e.g., McLeod et al., 1996; McLeod, Scheufele, \& Moy, 1999; Norris \& Jones, 1998; Shah et al., 2001, 2005). These effects tend to be consistent across traditional as well as new media (Hardy \& Scheufele, 2006). Mobile communication, as a hybrid medium, supports both information seeking and exchange, and these uses of the technology have been linked to increased involvement in civic and political life in the research so far (Campbell \& Kwak, 2010, in press). In other words, informational use of the mobile phone equips individuals to be more engaged citizens. Rather than drawing one's attention socially inward, this use of the technology helps broaden one's perspective, and therefore we expect (H5) that informational use will be positively associated with increased engagement with strangers in public settings.

\section{Interactive effects of mobile communication in public and forms of use}

So far, we have advanced separate sets of hypotheses regarding where one uses the mobile phone as well as how they use it (generally speaking). An important next step is to examine the interplay between these two contextual elements in predicting changes in engagement with strangers over time. Key aspects of the context surrounding media use often interact with one another in distinctive ways that lead to distinctive outcomes. For example, frequency of mobile communication with network ties interacts with the characteristics of those ties to predict various aspects of involvement in political life (Campbell \& Kwak, in press; Campbell et al., 2010). Thus, it is conceivable, if not likely, that engagement with strangers in public settings is influenced by the interaction between where they use mobile technology and how they use it. Because there is a lack of empirical and theoretical grounds to predict how each of the potential interactive effects will play out, we pose the following research question:

RQ1: How do differential forms of use enhance or mitigate the effects of mobile communication in public settings on engagement with strangers in these settings?

\section{Method}

The data for this study came from two waves of a national mail survey with a single panel of respondents. The data collection was conducted by the research firm Synovate. Synovate contacted a massive number of people via mail to ask their 
willingness to periodically participate in mail, telephone, or online surveys and if so, to provide basic demographic information. The sample for Wave 1 was drawn from this prerecruited mail panel of more than 500,000 people. To ensure representativeness, the sample for the W1 survey was selected to reflect demographic distributions within the five Census divisions of household income, population density, panel member's age, sex, and region. This stratified quota sampling method differs markedly from more conventional probability sample procedures yet produces highly comparable data (Putnam, 2000; Putnam \& Yonish, 1999).

In October 2008, W1 questionnaires were mailed to a total of 2,218 respondents. There were 66 undeliverable surveys, and 1,012 usable responses were received. Thus, the response rate for W1 was 47.0\%. In November 2008, W2 questionnaires were mailed to all W1 participants. A total of 717 respondents returned usable surveys in $\mathrm{W} 2$, which yielded a $70.8 \%$ retention rate.

Demographic characteristics of the W1 sample resemble the profiles of the national population figures reported in the U.S. Census Bureau's 2007 American Community Survey (ACS) with respect to education attainment (the median education level for those 25 or older in both data sets is some college), household income (the median in the ACS and the current study is $\$ 50,000-74,999$ and $\$ 50,000-59,999$, respectively), and age (the median age for those 18 or older in the ASC and the current study is 45-54 and 53, respectively). However, there is a greater percentage of male respondents in the sample (59.7\%) than in the ACS (48.6\%). W2 sample's demographic characteristics $(59.9 \%$ male; the median education level for 25 years or older respondents is some college; and the median household income is $\$ 50,000-59,999)$ are comparable with W1 sample's, except that the median age of the W2 sample is greater (56 years).

\section{Engagement with strangers in public}

To tap the extent to which respondents publicly interact with strangers, respondents were asked how frequently they had engaged in a conversation with a stranger in a public place on any topic. A 7-point scale, ranging from none in the last month to everyday was employed. The criterion variable for this study was from W2 $(M=2.27$, $S D=1.45)$, and the W1 measure of the same variable was included as a control variable $(M=2.39, S D=1.60)$.

\section{Use of mobile and portable media in public}

Respondents' use of mobile and portable media in public was measured by asking respondents to report how often they used personal media devices in public places with others around. A 5-point scale ranging from never to very often was used, and four devices were included in the W1 survey: mobile phone $(M=2.57, S D=1.48)$; iPod, MP3 player, or such device $(M=1.42, S D=.98)$; laptop $(M=1.48, S D=.98)$; and newspapers or magazines $(M=2.68, S D=1.29)$.

\section{Mobile communication patterns}

Three forms of mobile communication were included: coordination, relational use, and informational use. Each measure reflects an additive index for which two items 
were summed from the W1 survey. For all individual items, an 8-point scale, ranging from none in the last month to several times a day, was employed. For coordination, respondents were asked about how often they had contacted others via mobile communication to arrange meeting times and made contact with others to change plans $(M=6.04, S D=3.85$; interitem correlation $=.85)$. Relational use was measured by the frequency of using the mobile to call or text just to be social and to touch base just to say "Hi" to someone $(M=6.45, S D=4.42$; interitem correlation $=.82)$. Informational use was measured by the extent to which respondents sought out information about what was going on in the news and had discussed politics or other news by mobile phone $(M=3.47, S D=2.59$; interitem correlation $=.71)$. Of course, these forms of mobile communication may overlap in the sense that individuals can, and presumably do, utilize the technology for multiple purposes simultaneously. Thus, we do not treat these usage patterns as orthogonal in nature. Rather than attempting to untangle whether one used the technology for one reason or another at a given point in time, we examined usage tendencies more broadly to tease out the independent contribution of each to changes in the dependent variable over time.

\section{Control variables}

The analyses controlled for key demographics, including age, sex, education, and household income. Political interest was also controlled for because it has been found to influence numerous aspects of public life, such as political participation and discussing politics and public affairs with others (Campbell \& Kwak, 2010, in press; Campbell et al., 2010; Jeffres, Atkin, \& Neuendorf, 2002; Jennings \& Zeitner, 2003; Shah et al., 2001, 2005). To measure political interest, respondents were asked to state how much they agreed with the following statement, "I am very interested in politics," on a 6-point scale, ranging from definitely disagree to definitely agree $(M=3.47$, $S D=1.64$ ). We also controlled for level of social activity, thinking that people who are generally more social may also be more prone to engage with strangers in public settings. The measure for social activity entailed an additive index $(M=5.98, S D=2.56$, Cronbach's $\alpha=.66$ ) containing the sum of the following indicators, each on a 7-point scale ranging from none in the last month to every day: gave or attended a dinner party, entertained people in my home, and went out with a group of friends. In addition, we controlled for frequency of visits to public places, thinking that this may have an effect on encounters with strangers in public. This measure for public attendance $(M=$ $6.50, S D=2.75$, Cronbach's $\alpha=.55$ ) entailed an additive index of four items, each on a 7-point scale ranging from none in the last month to every day: went to a public library, attended college or school sports games, went to a community event, and went to a community or neighborhood meeting. All the control variables were measured in W1.

\section{Analysis}

Tests for direct and interactive effects of the patterns of use and mobile use in public were conducted using an ordinary least squares (OLS) lagged dependent variable 
regression model (Eveland \& Thomson, 2006). For this, prior to assessing the role of core independent variables on a dependent variable, the influence of the dependent variable at W1 had been accounted for. Thus, the coefficients for the independent variables could be interpreted as predicting change in the dependent variable above and beyond what would be expected from its prior values, strengthening causal inferences (Eveland \& Thomson, 2006; Finkel, 1995). To reduce potential problems with multicollinearity between interaction terms and their components, all the component variables were standardized prior to the formation of the interaction terms (Cronbach, 1987; Jaccard, Turrisi, \& Wan, 1990; Kwak, 1999).

\section{Results}

Table 1 depicts findings from OLS lagged dependent variable regression analyses of the direct effects for mobile phone use in public and the differential forms of use. The table shows that, contrary to our expectations, mobile phone use in public did not directly affect frequency of talking with new people in public settings. In fact, none of the media examined in this study directly affected this; thus, $\mathrm{H} 1$ and $\mathrm{H} 2$ were not supported. However, each of the patterns of use was significantly associated with public engagement in the ways anticipated in $\mathrm{H} 3-\mathrm{H} 5$. Mobile phone use for coordination and information about news both lead to increased public engagement, whereas relational use of the technology lead to a decrease in talking with new people in public settings.

Table 2 displays results of the interaction terms (RQ1), with one significant effect involving Informational Use $\times$ Use in Public. ${ }^{1}$ This interaction is plotted in Figure 1, which illustrates an increase in public conversations for those who frequently use their mobile phone for informational purposes and frequently use it in public settings.

\section{Discussion}

This study investigated how mobile communication helps and hinders the extent to which users meet and talk with new people in public places. We anticipated that mobile communication in public would have a negative effect on this by reducing opportunities for conversation to spark up among strangers. However, this position (H1) was not supported. There was no direct effect of mobile phone use in public, nor use of any other media examined (H2), on engaging with copresent strangers in public. However, subsequent findings reveal that the situation greatly depends on the ways in which one uses the technology, not just where they use it. By accounting for different types of appropriation, the study found evidence that mobile phone use in public actually facilitates talking with copresent strangers for those who also frequently rely on it to get and exchange information about news (RQ). This positive interaction sheds new light on the potential for mobile communication to help integrate unfamiliar people in publicly shared spaces and is therefore worthy of consideration.

It is important to bear in mind that this interaction effect is a product of two separate frequency measures, one for how often the mobile phone is used in public (regardless of how) and the other for how often it is used for news and information 
Table 1 Predictors of Engagement with Strangers in Public, Direct Relationships

\begin{tabular}{|c|c|c|}
\hline & \multicolumn{2}{|c|}{ Time 2 Engagement } \\
\hline & $\beta$ & $t$ Value \\
\hline \multicolumn{3}{|l|}{ Control variables } \\
\hline Time 1 engagement & $.49^{* *}$ & 14.40 \\
\hline Age & $-.07^{\#}$ & -1.70 \\
\hline Sex & $.07^{\#}$ & 1.94 \\
\hline Education & .04 & 1.05 \\
\hline Income & .01 & .23 \\
\hline Political interest & -.00 & -.11 \\
\hline Social activity & .05 & 1.31 \\
\hline Public attendance & .03 & 0.80 \\
\hline$R^{2}(\%)$ & \multicolumn{2}{|c|}{31.2} \\
\hline \multicolumn{3}{|l|}{ Public media variables } \\
\hline Mobile & .03 & 0.70 \\
\hline Laptop & -.04 & -0.85 \\
\hline Music device & -.04 & -0.92 \\
\hline Print materials & -.02 & -0.40 \\
\hline Inc. $R^{2}(\%)$ & \multicolumn{2}{|c|}{0.3} \\
\hline \multicolumn{3}{|c|}{ Mobile communication patterns } \\
\hline Coordination & $.18^{* *}$ & 3.61 \\
\hline Relational & $-.16^{* *}$ & -3.09 \\
\hline Informational & $.09^{*}$ & 2.30 \\
\hline Inc. $R^{2}(\%)$ & \multicolumn{2}{|c|}{2.3} \\
\hline Total $R^{2}(\%)$ & \multicolumn{2}{|c|}{33.8} \\
\hline
\end{tabular}

Note: Entries are standardized final regression coefficients. $N=631\left({ }^{*} p<.10 .{ }^{*} p<.05\right.$. $\left.{ }^{* *} p<.01\right)$.

Table 2 Predictors of Engagement with Strangers, Interactive Effects

\begin{tabular}{|c|c|c|}
\hline & \multicolumn{2}{|c|}{ Time 2 Engagement } \\
\hline & $\beta$ & $t$ Value \\
\hline Prior blocks $R^{2}(\%)$ & \multicolumn{2}{|c|}{33.8} \\
\hline \multicolumn{3}{|c|}{ Mobile phone use in public $\times$} \\
\hline Use for coordination & -.03 & -0.91 \\
\hline Relational use & .02 & 0.62 \\
\hline Informational use & $.08^{*}$ & 2.19 \\
\hline Inc. $R^{2}(\%)$ & \multicolumn{2}{|c|}{0.9} \\
\hline Total $R^{2}(\%)$ & \multicolumn{2}{|c|}{34.7} \\
\hline
\end{tabular}

Note: Prior blocks include T1 engagement, age, sex, education, household income, political interest, social activity, public attendance, public media usage variables, and mobile usage pattern variables. Entries are standardized regression coefficients after controlling for the prior blocks. $N=631\left({ }^{*} p<.05\right)$. 


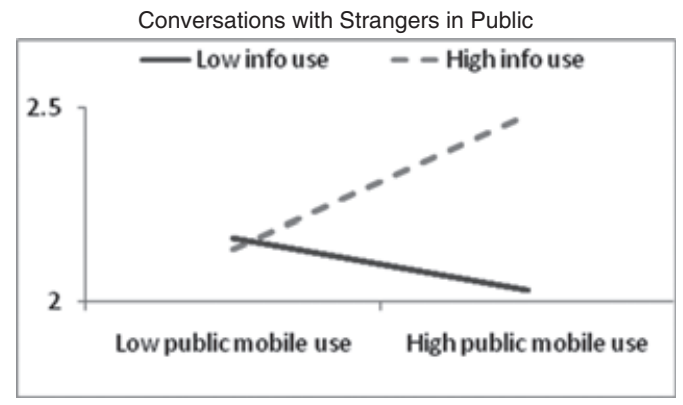

Figure 1 Predicting public engagement with Informational Mobile Use $\times$ Use in Public.

(regardless of where). Thus, we infer that the significant interaction between the two is reflective of heightened levels of informational use of the technology while in public settings. The increase in public engagement associated with this activity may be because of users having more relevant fodder for conversing with strangers, coupled with increased motivation to do so. Compared with mobile-mediated exchanges regarding one's own private affairs, those regarding public affairs are much more germane to the lives of others in the community at large, giving the user something relevant to discuss with unknown others in public settings. Furthermore, using mobile technology to get and exchange news in public may have the added benefit of heightened information salience, boosting one's motivation to talk about it with others nearby. Presumably, information is particularly salient during and immediately after exposure to it, and this heightened salience may translate into increased willingness to discuss it with others while it is newly processed. That is, frequent use of the mobile phone in public and as a resource for news may help bring unfamiliar people together in dialogue by providing shared topics of conversation that are also salient because they are fresh on the user's mind. Future research in this area should develop these plausible explanations into testable hypotheses, while also identifying other mechanisms for the significant increase in talking with strangers in public under these conditions.

In building up to the tests of the interactive effects, we also examined the direct effects that different forms of mobile communication have on engaging with strangers in public. In addition to its interactive effect with use in public, informational use in general had a positive effect (H5). That is, this use of the technology was associated with increased engagement with strangers - not just for those who do it in public but especially for them. This finding is not surprising considering use of other media, both traditional and new, for surveillance of public affairs tends to play a positive role in civil society by providing individuals with information to reflect and deliberate on public matters (see, e.g., McLeod et al., 1996, 1999; Shah et al., 2005).

This evidence for positive effects of informational use of the technology is encouraging, considering the rapid evolution of mobile telephony into a channel for mass communication. Formerly just a point-to-point medium, mobile technology increasingly supports accessing and sharing information about public affairs through 
data services. These capabilities will only increase as more users adopt smart phones and high-speed data plans, making use of the medium as an informational resource less cumbersome and more widespread. According to Smith (2010), the percentage of adults in the United States who use the mobile phone for Internet, e-mail, or instant messaging jumped from $32 \%$ in 2009 to $40 \%$ in 2010 . This finding reveals significant growth in these activities with abundant opportunity for continued growth. In other words, we are only starting to realize the use and potential of mobile communication as a fully networked medium. As its role for accessing and exchanging mass-mediated content continues to evolve, so too might its role in facilitating engagement in civil society, warranting continued research in this area.

At the same time, the evolution of mobile communication as an informational resource conjures Sunstein's (2001) concerns about selective exposure and filtering of news in the contemporary media environment. Like the computer, mobile telephony is highly personalized, allowing users to be selective in the news they retrieve. The technology is also highly selective with regard to whom one uses it with, a phenomenon Matsuda (2005) characterizes as selective sociality. The technology is selectively used with close personal ties (Ling, 2008) not only for private purposes but also to discuss and share information about politics and public affairs (Campbell et al., 2010; Campbell \& Kwak, in press). Thus, mobile technology is characteristically selective both technologically and socially, and these attributes lend themselves to a "daily me" information environment (Negroponte, 1995; Sunstein, 2001). Yet, these concerns about insularity appear to be mitigated by increased conversations with strangers in public settings when the technology is used for news, particularly while the user is in these shared settings. In other words, despite being a highly individualized medium, mobile communication has the potential to foster a sense of "we" in public life, although only when used in certain ways. An avenue for future research will be to examine whether the direction of causality also flows in the other direction. Slater (2007) argues that there tends to be a mutual influence between media use and media effects. In this case, it seems highly plausible that talking with strangers in public settings exposes individuals to new information, prompting them to elaborate on it through mobile communication. Therefore, further investigation on the reciprocal effects of informational use of mobile technology and engagement in the public realm is warranted.

Like informational use, use for coordination was also associated with an increase in talking with unknown others in public. As noted in the framing of $\mathrm{H} 3$, a likely explanation is that anytime-anywhere coordination helps facilitate increased presence in public settings by affording heightened flexibility for busy people to move about while coordinating their affairs. This flexibility not only allows them to move about more freely from place to place but also prompts them to use public settings as hubs for meeting up with others. In other words, use of the mobile phone for microcoordination (Ling \& Yttri, 1999, 2002; Ling, 2004) may lead to more frequent conversations with strangers vis-à-vis the user's increased presence in public places. This plausible explanation provides another avenue for future research, specifically testing the hypothesis that use of the technology for coordination leads to increased 
presence in public settings with others around, which, through opportunity, leads to increased conversations with copresent bystanders.

In contrast to use for information and coordination, frequent relational use of the technology was associated with fewer conversations with strangers in public. This finding bolsters concerns that intensive mobile-mediated contact with friends, family, and intimates can have a cocooning effect on social life by focusing one's attention on existing personal relationships at the expense of bridging out to new people (Campbell et al., 2010; Campbell \& Kwak, in press; Gergen, 2002, 2008; Habuchi, 2005; Ling, 2008). Because this is a direct effect for overall levels of relational use and not an interaction with use in public, one might infer that this type of insularity is more of a general orientation rather than situational absent presence around copresent others. However, before accepting this interpretation, future research is needed to further examine the nuances surrounding use of the technology as a relational resource. For example, recent studies indicate that social network characteristics play an important role in whether mobile communication with close personal ties leads to social withdrawal. Use of the technology in strong-tie networks that are both small and likeminded has been linked to less civic engagement and political discourse outside the network, whereas use of the technology in homogenous networks that are large yielded opposite trends with increased engagement (Campbell \& Kwak, in press) and open dialogue (Campbell et al., 2010). Thus, a more nuanced account of with whom one uses the technology is needed to understand whether and how its use for maintaining personal relationships contributes to closing oneself off from others in public.

Because this is foundational work, future research is needed to corroborate and extend on the findings in other ways as well. In addition to use in public, the scope of the study was focused on the effects of content patterns during mobilemediated exchanges, as opposed to the technological features used. Future research with an emphasis on features such as voice, text, pictures/videos, and the Web will complement this study while providing a more nuanced account of the ways mobile communication helps and hinders public interaction. Future studies extending on our examination of content patterns should be more nuanced as well. The forms of use in this study reflect three of the primary ways in which people use mobile technology; however, they are far from exhaustive. One additional form of use that especially warrants investigation is recreation. Mobile games and entertainment are becoming increasingly popular (Katz \& Acord, 2008), which may have important implications for engaging with others in public settings. Recreational use of the media is a major theme in the U\&G tradition and research on public life (e.g., Campbell \& Kwak, 2010; McQuail, 1985, 1987; Shah et al., 2001; Zillman, 1985), providing a logical next step for expanding on the range of mobile phone usage behavior. Another area in which greater nuance is needed is in differentiating between different types of public settings. This study examined the public realm generally, yet it is conceivable that individuals use mobile technology in differential ways with differential effects in disparate types of public places. To illustrate, Hampton et al. (2010) investigated wireless Internet use in public settings and found that in some cases, interaction with copresent strangers was 
influenced by the configuration of the setting. Thus, it would be fruitful to account for such contextual aspects in future research on mobile communication in public.

\section{Concluding remarks}

This study provides notably different insights than those offered in previous research and theory on mobile communication in public settings. To date, most of the scholarship in this area has sought to explain why use of the technology in public is disturbing to copresent bystanders, how users attempt to mitigate the intrusion, and how new norms are established and old ones enforced (e.g., Campbell \& Russo, 2003; Hoflich, 2006; Humphreys, 2005; Katz, 2006; Ling, 2004; Okabe \& Ito, 2005). This study differs from most by taking a user-centered approach to examine serendipitous engagement with strangers, with an eye toward implications for civil society. Notably, Hampton et al. (2010) take a similar approach in their recent study on personal media use in public. However, unlike this study, their study suggests that mobile communication in public largely inhibits attentiveness to one's physical surroundings as well as interaction with strangers. While this may be the case, it also greatly depends on how one uses the technology. Thus, the contribution of this study lies in its account of differential usage patterns, some of which actually contribute to broadening engagement in the public realm. Efforts to further develop this line of inquiry will benefit by extending on these findings while continuing to add nuance to measures that capture how, where, and with whom users appropriate mobile communication technology.

\section{Note}

1 To examine whether the items for informational use of the mobile phone (i.e., discussing politics and public affairs and seeking news online) operate differently, we ran posthoc regression analyses with each item separately. Mobile-mediated discussion was a marginally significant direct predictor of public engagement $(\beta=.07, t=1.75, p<.10)$ and had a marginally significant interaction effect with use in public $(\beta=.07, t=1.82$, $p<.10)$. Seeking news online via a mobile was a significant direct predictor of public engagement $(\beta=.08, t=2.25, p<.05)$ and had a significant interaction effect with use in public ( $\beta=.08, t=2.06, p<.05)$. Thus, the two items, when treated separately, yielded consistent patterns with each other as well as the original variable for informational use of the mobile phone, which is not surprising considering they are highly correlated $(r=.70)$.

\section{References}

Aleo-Carreira, C. (2008, November 6). Did social media decide the U.S. presidential election in Obama's favor? PC World. Retrieved January 13, 2011, from http://www.pcworld.com/ businesscenter/article/153405/did_social_media_decide_us_presidential_electron.html

AT\&T. (2008, November 6). AT\&T reports largest text messaging spike in company history on election night [Press release]. Retrieved January 13, 2011, from http://www.att.com/ gen/press-room?pid $=4800 \& \mathrm{cdvn}=$ news $\&$ newsarticleid $=26287 \&$ mapcode $=$ consumer 
Besley, J. C. (2006). The role of entertainment television and its interactions with individual values in explaining political participation. Harvard International Journal of Press/Politics, 11(2), 41-63.

Bessette, J. M. (1980). Deliberative democracy: The majority principle in republican government. In R. Goldwin \& W. Shambra (Eds.), How democratic is the constitution? (pp. 102-116). Washington, DC: American Enterprise Institute.

Bessette, J. M. (1994). The mild voice of reason: Deliberative democracy \& American national government. Chicago: University of Chicago Press.

Blumler, J. G., \& Katz, E. (Eds.). (1974). The uses of mass communications: Current perspectives on gratifications research. Beverly Hills, CA: Sage.

Campbell, S. W., \& Kwak, N. (2010). Mobile Communication and civic life: Linking patterns of use to civic and political engagement. Journal of Communication, 60, 563-555.

Campbell, S. W., \& Kwak, N. (in press). Political involvement in "mobilized" society: The interactive relationships among mobile communication, network characteristics, and political participation. Journal of Communication.

Campbell, S. W., Kwak, N., Bae, S.-Y., Brown, K., Lee, H., \& Yu, R. (2010, August). Mobile Communication and the Personalization of Public life: Implications for open dialogue. Paper presented at the annual meeting of the Association for Education in Journalism and Mass Communication, Denver, Co.

Campbell, S. W., \& Russo, T. C. (2003). The social construction of mobile telephony: An application of the social influence model to perceptions and uses of mobile phones within personal communication networks. Communication Monographs, 70(4), 317-334.

Castells, M. (2009). Communication power. New York: Oxford University Press.

Cohen, J. (1989). Deliberative democracy and democratic legitimacy. In A. Hamlin \& P. Pettit (Eds.), The good polity (pp. 17-34). Oxford: Blackwell.

Cronbach, L. J. (1987). Statistical tests for moderator variables: Flaws in analyses recently proposed. Psychological Bulletin, 102, 414-417.

Eveland, W. P., \& Thomson, T. (2006). Is it talking, thinking, or both? A lagged dependent variable model of discussion effects on political knowledge. Journal of Communication, 56(3), 523-542.

Finkel, S. E. (1995). Causal analysis with panel data (Sage University Paper Series on Quantitative Applications in the Social Sciences, 07-105). Thousand Oaks, CA: Sage.

Finn, S. (1997). Origins of media exposure: Linking personality traits to TV, radio, print, and film use. Communication Research, 24, 507-529.

Gergen, K. J. (2002). The challenge of absent presence. In J. Katz \& M. Aakhus (Eds.), Perpetual contact: Mobile communication, private talk, public performance (pp. 227-241). Cambridge, UK: Cambridge University Press.

Gergen, K. J. (2008). Mobile communication and the transformation of the democratic process. In J. Katz (Ed.), Handbook of mobile communication studies (pp. 297-310). Cambridge, MA: MIT Press.

Habermas, J. (1989). The structural transformation of the public sphere: An inquiry into a category of bourgeois society. Cambridge, MA: MIT Press.

Habuchi, I. (2005). Accelerating reflexivity. In M. Ito, D. Okabe, \& M. Matsuda (Eds.), Personal, portable, pedestrian: Mobile phones in Japanese life (pp. 165-182). Cambridge, MA: MIT Press. 
Hampton, K. N., Livio, O., \& Goulet, L. S. (2010). The social life of wireless urban spaces: Internet use, social networks, and the public realm. Journal of Communication, $\mathbf{6 0}$, $701-722$.

Hardy, B. W., \& Scheufele, D. A. (2006). New media and democratic citizenship. Encyclopedia of digital government (Vol. III, pp. 1250-1254). Hersney, PA: IGI Publishing.

Hoflich, J. R. (2006). Places of life: Places of communication. In J. R. Hoflich \& M. Hartmann (Eds.), Mobile communications in everyday life (pp. 19-51). Berlin, Germany: Frank \& Timme.

Humphreys, L. (2005). Cellphones in public: Social interaction in a wireless era. New Media \& Society, 7, 813-836.

Humphreys, L. (2007). Mobile social networks and spatial practice: A case study of Dodgeball. Journal of Computer-Mediated Communication, 13(1). Retrieved from http://jcmc.indiana.edu/vol13/issue1/humphreys.html

Jaccard, J., Turrisi, R., \& Wan, C. K. (1990). Interaction effects in multiple regression. Newbury Park, CA: Sage.

Jeffres, L. W., Atkin, D., \& Neuendorf, K. A. (2002). A model linking community activity and communication with political attitudes and involvement in neighborhoods. Political Communication, 19, 387-421.

Jennings, M. K., \& Zeitner, V. (2003). Internet use and civic engagement: A longitudinal analysis. Public Opinion Quarterly, 67, 311-334.

Katz, J. E. (2006). Magic in the air. New Brunswick, NJ: Transaction.

Katz, J. E., \& Aakhus, M. A. (Eds.). (2002). Perpetual contact: Mobile communication, private talk, public performance. Cambridge, UK: Cambridge University Press.

Katz, J. E., \& Acord, S. K. (2008). Mobile games and entertainment. In J. Katz (Ed.), Handbook of mobile communication studies (pp. 403-418). Cambridge, MA: MIT Press.

Kwak, N. (1999). Revisiting the knowledge gap hypothesis: Education, motivation, and media use. Communication Research, 26, 385-413.

Leung, L., \& Wei, R. (2000). More than just talk on the move: Uses and gratifications of the cellular phone. Journalism and Mass Communication Quarterly, 77, 308-320.

Ling, R. (2004). The mobile connection: The cell phone's impact on society. San Francisco: Morgan Kaufman.

Ling, R. (2008). New tech, new ties: How mobile communication is reshaping social cohesion. Cambridge, MA: MIT Press.

Ling, R., \& Campbell, S. W. (Eds.). (2009). Reconstruction of space and time: Mobile communication practices. New Brunswick, NJ: Transaction.

Ling, R., \& Yttri, B. (1999). Nobody sits at home and waits for the telephone to ring: Micro and hyper-coordination through the use of the mobile phone (Report 30/99). Kjeller, Norway: Telenor Research and Development.

Ling, R., \& Yttri, B. (2002). Hyper-coordination via mobile phones in Norway. In J. Katz \& M. Aakhus (Eds.), Perpetual contact: Mobile communication, private talk, public performance (pp. 139-169). Cambridge, UK: Cambridge University Press.

Matsuda, M. (2005). Mobile communication and selective sociality. In M. Ito, D. Okabe, \& M. Matsuda (Eds.), Personal, portable, pedestrian: Mobile phones in Japanese life (pp. 123-142). Cambridge, MA: MIT Press.

McLeod, J. M., Daily, K., Guo, Z., Eveland, W. P., Jr., Bayer, J., Yang, S., et al. (1996). Community integration, local media use and democratic processes. Communication Research, 23(2), 179-209. 
McLeod, J. M., Scheufele, D. A., \& Moy, P. (1999). Community, communication, and participation: The role of mass media and interpersonal discussion in local political participation. Political Communication, 16, 315-336.

McQuail, D. (1985). Gratifications research and media theory: Four models or one. In K. E. Rosengren, L. Wenner, \& P. Palmgreen (Eds.), Media gratifications research: Current perspectives (pp. 149-167). Beverly Hills, CA: Sage.

McQuail, D. (1987). The functions of communication: A non-functionalist overview. In C. R. Berger \& S. H. Chaffee (Eds.), Handbook of communication science (pp. 327-346). Beverly Hills, CA: Sage.

Negroponte, N. (1995). Being digital. New York: Vantage.

Norris, P. (1996). Does television erode social capital? A reply to Putnam. PS: Political Science and Politics, 29, 474-480.

Norris, P., \& Jones, P. (1998). Virtual democracy. Harvard International Journal of Press/Politics, 3(2), 1-4.

Okabe, D., \& Ito, M. (2005). Keitai in public transportation. In M. Ito, D. Okabe, \& M. Matsuda (Eds.), Personal, portable, pedestrian: Mobile phones in Japanese life (pp. 205-218). Cambridge, MA: MIT Press.

Putnam, R. D. (2000). Bowling alone: The collapse and revival of American community. New York: Simon \& Schuster.

Putnam, R. D., \& Yonish, S. (1999, May). How important are random samples? Some surprising new evidence. Paper presented to the annual meeting of the American Association of Public Opinion Research, St. Petersburg, FL.

Shah, D. V., Cho, J., Eveland, W. P., Jr., \& Kwak, N. (2005). Information and expression in a digital age: Modeling Internet effects on civic participation. Communication Research, 32, 531-565.

Shah, D. V., Kwak, N., \& Holbert, R. L. (2001). "Connecting" and "disconnecting" with civic life: Patterns of Internet use and the production of social capital. Political Communication, 18(2), 141-162.

Slater, M. D. (2007). Reinforcing spirals: The mutual influence of media selectivity and media effects and their impact on individual behavior and social identity. Communication Theory, 17(3), 281-303.

Smith, A. (2010). Mobile access 2010. A report from the Pew Internet \& American Life Project. Retrieved from http://www.pewinternet.org/Reports/2010/Mobile-Access- 2010.aspx

Sotirovic, M., \& McLeod, J. M. (2001). Values, communication behavior, and political participation. Political Communication, 18(3), 273-300.

Sunstein, C. R. (2001). Republic.com. Princeton, NJ: Princeton University Press.

University of Michigan. (2006). On the move: The role of cellular communications in American life. Ann Arbor, MI. Retrieved from http://itudcmc.files.wordpress.com/2010/03/ onthemove1.pdf

Wei, R. (2008). Motivations for using the mobile phone for mass communications and entertainment. Telematics and Informatics, 25(1), 36-46.

Wei, R., \& Lo, V.-H. (2006). Staying connected while on the move: Cell phone use and social connectedness. New Media \& Society, 8(1), 53-72.

Zillman, D. (1985). The experimental explorations of gratifications from media entertainment. In D. Zillman \& J. Bryant (Eds.), Selective exposure to communication (pp. 225-239). Hillsdale, NJ: Erlbaum. 
移动通信与文明社会：使用方式和地点与在公共场合和陌生人交流的关系

\section{【摘要 : 】}

本文研究移动通信是否以及如何影响人在公共场所与陌生人的交流。与我们的预料相 反，该技术在公共场合普遍应用并未减弱与陌生人的交谈。通过关注人们如何使用技术而 不是在哪里使用，我们发现以协调和汶览新闻为目的的使用会增加在公共场合与陌生人的 交谈，而以联系为目的的使用则减少这种交流。调查结果还显示了一个互动的作用，即那 些用移动通信工具看新闻, 并经常使用移动技术的人在公共场合更愿与陌生人谈话。本文 最后讨论了对研究结果的解释和未来研究的方向。 
La communication mobile et la société civile : les liens entre les types et lieux d'usage et les interactions avec les autres en public

Cette étude a cherché à savoir si et comment la communication mobile influence l’importance avec laquelle on interagit avec des personnes nouvelles dans des contextes publics. Contrairement à nos attentes, l’usage général de cette technologie en public n’a pas diminué la conversation avec des étrangers. En examinant comment les gens utilisent leurs téléphones mobiles plutôt qu'où ils les utilisent, nous avons découvert que les usages visant la coordination ou les nouvelles menaient à une augmentation des conversations avec des étrangers dans des contextes publics, tandis que l'usage relationnel diminuait ces conversations. Les résultats révèlent également un effet interactif : ceux et celles qui utilisent la technologie mobile pour les nouvelles et qui l'utilisent fréquemment en public ont plus tendance à interagir avec des étrangers en public. La discussion offre une interprétation des résultats et des suggestions d'études futures.

Mots clés : communication mobile, téléphone mobile, téléphone cellulaire, société civile, espace public, contextes publics 
Mobilkommunikation und Zivilgesellschaft: Der Zusammenhang von Nutzungsmustern und -orten mit der Interaktion mit Anderen in der Öffentlichkeit

Die Studie untersucht, ob und wie Mobilkommunikation das Ausmaß beeinflusst, mit dem man mit fremden Menschen in der Öffentlichkeit interagiert. Anders als erwartet lenkt die allgemeine Nutzung dieser Technologie in der Öffentlichkeit nicht davon ab, sich mit Unbekannten zu unterhalten. Wendet man den Fokus weg vom „Wo“ hin zum „Wie“ jemand das Mobiltelefon nutzt, zeigte sich, dass die Nutzung zur Koordination und für Nachrichten häufiger zu Gesprächen mit Unbekannten in der Öffentlichkeit führte, während ein beziehungsbezogener Gebrauch eher ablenkte. Die Ergebnisse zeigen auch einen interaktiven Effekt, insofern als dass diejenigen, die Mobiltechnologie für Nachrichten und vermehrt in der Öffentlichkeit nutzen eher mit Unbekannten in der Öffentlichkeit interagieren. Die Diskussion bietet eine Interpretation der Ergebnisse und zeigt Möglichkeiten für zukünftige Forschung.

Schlüsselbegriffe: Mobilkommunikation, Mobiltelefon, Handy, Zivilgesellschaft, Öffentlichkeit, öffentliche Schauplätze 
Mobile Communication and Civil Society: Linking Patterns and Places of Use to Engagement with Others in Public

모바일 커뮤니케이션과 시민사회: 타자들과의 연계에 대한 사용의 연계형태와 위치들

요약

본 연구는 모바일 커뮤니케이션이 공적인 상황에서 한사람이 새로운 사람들과의 관계를 확대할 수 있느냐 없느냐, 그리고 어떻게 이러한 관계를 확대할 수 있느냐에 대한 것이다. 우리들의 기대와는 반대로, 기술의 대중적 이용은 이방인들과의 대화를 저해하지 않았다. 어디서 모바일전화를 사용하는가에서 어떻게 이를 이용하는가로 초점을 바꾸었을때, 우리는 조정과 뉴스를 위한 사용은 공적인 성황에서 이방인들과의 대화를 증대시키는 것으로 나타난 반면, 상대적 사용은 이를 저해하는 것으로 나타난다는 것을 발견했다. 발견들은 또한 모바일 기술을 뉴스를 위해 사용하거나 그리고 이를 대중적으로 자주 사용하는 사람들은 이방인들과 더 자주 연계할 가능성이 있는 것으로 나타났다. 본 연구는 이러한 발견들의 해석과 미래 연구를 위한 방향들을 제시하였다. 